\title{
THE JOURNALIST IMAGE IN THE WORKS OF MASS CULTURE OF THE RUSSIAN FEDERATION
}

\author{
Roman P. Bakanov ${ }^{1}$ \\ Kirill I. Zaysanov ${ }^{2}$ \\ Dmitrii V. Tumanov ${ }^{3}$
}

\begin{abstract}
The article reveals the terms of modern journalism, analyses the journalist images created in the mass culture of the Russian Federation. It is not easy to find out the journalist image on pages of mass editions and in fulllength feature films. In various stages of the Russian society formation, the journalist appeared in this type of works with the goal of personifying a certain ideology. Today, the comic characters are pushed into the background by a solid superhero nature, the audience often discusses the relationship between heroes than who they are in the series, the films emphasize the epic nature of the action, and the journalist is usually a way of creating a work in the "action" genre in fiction. The Russian journalist image is often negative: it is either a
\end{abstract} "hatchet" man from the tabloid press, or gossip "collector", or a careerist. Such characters much less often become the main participants in criminal events, seeking the triumph of justice and the establishment of truth in the society. The main task of the authors when creating such works with the charactersjournalists is to provide material interesting to the consumer. Transformation of any product, including spiritual, into a good, dictates the special conditions for creating the journalist image. Based on the universal journalist image, identified by $D$. Randall (2000) [1], we typologized the characters, having revealed certain regularities. The results of our study consist in confirming the expected results: the creators of mass culture

\footnotetext{
1 Kazan Federal University - Kazan, Kremlevskaya st., 18, 420008. E-mail: rbakanov@yandex.ru.

2 Kazan Federal University - Kazan, Kremlevskaya st., 18, 420008. E-mail: uragiri@mail.ru,

3 Kazan Federal University - Kazan, Kremlevskaya st., 18, 420008. E-mail: dvt1964@yandex.ru
} 
products do not set themselves the task of objectively demonstrating the journalist profession; journalism appears in a grotesque image in their works.

Keywords: journalist, image, portrait, mass culture, comics, television, cinema, fiction.

\section{Introduction}

The purpose of this article is to reveal the characteristics of the journalist image created in the products of mass culture. We will consider journalism from the point of view of today's realities of the Russian Federation.

A universal journalist is a multifunctional worker who can write on virtually any topics and owns the method of creating a journalistic work for any type of mass media. He knows the basics of a large number of specialties, but he cannot boast of deep knowledge in any field. At the same time, he does not strive for objectivity in facts submitting, for revealing the truth, his priority is promptness in providing material to the editorial staff.
In this he differs from an ideal journalist, who is characterized, first of all, by social responsibility.

The ideal journalist strives for a high-quality journalistic based on reliable proven facts, the purpose of which is to convey the truth to readers, to whatever social stratum they belong to. He puts everything in doubt, is able to seek and publish only proven information fixed in the official sources, does not depend on power, is not controlled by anyone, impartially looks at the world around him and destroys myths and so on. His main goal is to organize the victory of good and justice.

These two journalist models universal and ideal - become polar when creating the journalist image in the works of mass culture. The universal journalist appears on the screen as bright, successful, self-satisfied, but necessarily committing gross violations of professional ethics, and the ideal journalist is invisible, unsuccessful in his personal life, excessively modest, but fearless and corrosive in the performance of professional duty.

The authors of this article understand the term definition of "mass culture" given by G.I. Markova (1996) as 
ISSN | 2179-7137 | http://periodicos.ufpb.br/ojs2/index.php/ged/index

"a phenomenon that characterizes the specific features of the production of cultural values in modern society. It is assumed that the mass culture is consumed by all people, regardless of the place and country of their residence. The culture is called mass also because it is massively produced on a daily basis. It is the everyday life culture, given to the audience by the mass media" [2].

The journalist image in the works designed for a broad mass audience has been created for more than a decade. There are the representatives of different eras, styles and directions among their authors - Guy de Maupassant, Arthur Conan Doyle, Mark Twain, Ernest Hemingway, Hunter Thompson, Stig Larsson, Gunther Grass, Arthur Haley and many others.

The journalist image was displayed on the screens of the world cinema in the following movies: "Roman Holiday" by William Wyler, "La Dolce Vita" by Federico Fellini, "Wag the Dog") by Barry Levinson, "Professione: reporter") by Michelangelo Antonioni, "All the President's Men" by Alan Pakula, "The Shattered Glass" by Billy Ray and many others.
Over the past few years, the journalist has increasingly become one of the characters of the Russian mass culture works (books, television series and movies). He can carry the function of "hero" or "villain" in the story, but his professional skills, his abilities and duties are not affected in any way.

The problem of journalism representation in the Russian mass culture has only recently become the subject of scientific reflection. Over the past few years, it has been published only one scientific work "The Age of Superheroes: Roots, History, Ideology of the American Comics" by D.G. Dmitrieva (2015) [3] concerning comics and their influence on the Russian market. The researcher V.M. Khalilov (2007) has considered the journalist image in the US cinema [4] and how it influences the perception of such profession in Russia. The scientific work of K.M. Antipova (2013) [5] is devoted to the formation of the journalist media image in contemporary cinema, many Russian researches (for example, V.L. Tsvik, Ya.V. Nazarova, G.V. Lazutina (2006) [6] et al.) have studied the essence of the creative activity of a television journalist. 
The results of our study are supplemented by Russian examples of $\mathrm{E}$. King and R. Reddick (2000) [7], S. Denson, C. Meyer, D. Stein (2013) [8], N. Newman (2009) [9], M. Deuze (2004) [10], M. Ehrlich (2004) [11] in the field of forming media images of representatives of various kinds of activities in the mass media, including journalist in the works of mass culture.

\section{Methods}

The chronological period of the study covers seven years (2008-2015), during this time several works were presented, the heroes of which were the journalists.

The empirical basis of the study was represented by the following printed works of mass culture of the Russian Federation: ironic detective, corresponding to the American TV series "Angel on a Broom" from the cycle "Investigation Gentleman: Ivan Podushkin" by D. Dontsova (2008); satirical novel "The Quails. The Story of Unreal Love" by S. Minaev (2008) and detective Russian comics "Major Grom" (2012-2015). We have also studied the audiovisual works: Russian TV series
"Local News" (2013) and romantic comedy "Urgent Marry" (2015). The journalists-heroes were the main characters in the works selected for study.

We examined different genres and years to reveal how the journalist image transformed in the interpretation of the authors of books and TV series in the early XXI century.

When carrying out the research, we applied the following methods:

1) an inclusive analysis of the works of mass culture selected for study, which enabled us to identify methods of forming the journalist image. Having understood how a particular author sees his characters, we were able to determine the features of each of the heroes and their correspondence to the scientific view of the journalist profession;

2) a structural analysis of the content of works, which created an empirical basis to study the change in the characters' temper in the course of plot development, possible destruction of the personality type for the sake of plot development. Having considered the formation of heroes, we were able to understand how important they were to 
the authors as the professionals in their field.

3) a comparative analysis of the images of journalists-heroes in the works of mass culture, which constituted the empirical basis of research, and the real journalist.

\section{Results}

1. Both universal and ideal journalists should achieve a lot in order to have the right to be so called. This is a hard way, which requires to work extremely hard on yourself, improving both your temper and creativity, and always thinking about every event as a potential publication and giving yourself to the profession in whole.

2. Having identified the principles of creative and ethical activity that should be observed by current journalists, we were able to fully imagine the image of a modern journalist, built in the mass consciousness of the audience, which was similar to the image of the universal journalist by David Randall.

3. Having described the journalists in the selected works (their views on life, values and professional qualities) and having compared their images with real journalists, we have realized how much the authors and writers are trying to get close to reality, touch urgent and important problems.

4. Journalists in the television series are kind, honest and will never allow themselves to commit acts that are contrary to their moral guidelines.

The heroes of comics and books are diverse, they are united by a desire to search for information, the opportunity to find "news of the day" and the ability to control people as puppets.

In feature films, the journalism was presented only as an addition to the character characteristics as a way to "move" the character in space.

A journalist is a brave, honest, eager to do everything for success, smart and sharp-tongued person, but his human qualities take precedence over professional ones in the works of mass culture studied by us.

5. The dynamics of the plot development has been in the first place, while the transfer of modern realities is not the most important for the authors of the works that have formed the empirical basis of this study. This is due to the common conviction of the creators of comics, television series, books and films, that the journalism is not able to 
ISSN | 2179-7137 | http://periodicos.ufpb.br/ojs2/index.php/ged/index

influence on the society and change the socio-political conditions in Russia.

So, what kind of journalists does appear in Russian mass media?

1. Going to die. Yuliya Pchelkina, the character of the comics "Major Grom", a very brave girl, ready for anything for the sake of truth. She provides her boyfriend with an invaluable service, helping to track down the antagonist and exposing the sins of billionaire Sergey Razumovskiy already in the first plot. Without the participation of Yuliya, history would not have been publicized, since it was the girl who worked on television that was able to convey to the audience all the facts as quickly and believably as possible. Her professional skills were somewhat blurred in the following plots.

The reader can see a professional subtext behind the tragic romance unfolding in the comics. Yuliya thinks like a journalist: She worries that the public should receive only the facts without a mixture of lies and guile. She is brisk and impudent to some extent. There is only one ethics for her - the ethics of the television company in which she works. No one can influence her opinion, not even her boyfriend. As a result, she dies.

2. Unprincipled trader. Sergey Mityaev - the chief editor of the newspaper "Chas Pik", which became a source of gossips, scandals, intrigues, investigations - the hero of the book "Angel on the Broom" by Darya Dontsova. The detective Ivan Podushkin, the main character of the novel, characterizes him like this: "I know very well the motto of the scribblers: "All for sale". Sergey Mityaev does not care how, about whom and what to write; the main thing for him is how much and when he will be paid for it. He is ready to falsify the article about the oligarch or blackmail the husband of a "stupid singer" with the supposed scandalous photos of his wife to pay for his new car.

$\underline{\mathrm{He} \text { is generally characterized in }}$ this book as: "Modern journalism professes one principle: "First we'll get the facts, and then we can distort them as we like!"

3. Coward careerist. The writer $\underline{\text { Sergey Minaev represents the image of a }}$ narcissistic, selfish, vulgar, cynical, capricious and coward journalist to the audience who only writes about what his leadership wants to read in his novel 
ISSN | 2179-7137 | http://periodicos.ufpb.br/ojs2/index.php/ged/index

"The Quails". He does not have his own opinion, believing that "the main thing is not victory, but participation in the fight against oneself". He is afraid of being himself, sincerely believing that it is better to be part of the crowd: "The best mean for uniting the masses in a fit of popular anger is to unite, to harass and to drive out a fledged single from the herd".

4. Romantic idealist. A collective portrait of a contemporary Russian journalist can be seen in the characters of the TV series "Local News".

The photographer Maxim is still young, he does not understand much, but tries to get to the truth, to reveal and correctly interpret all the causes and consequences of human actions.

Marina is a good psychologist when she has to write a custom-made article, she switches on her fantasy, violating the professional requirements of authenticity, and creates a journalistic story based on the hero's dream. She is honest, open, trustful, always takes into account the opinion of the audience. She has her own column for the youngest in the newspaper. She also often writes in the column "Checked by oneself".

$\underline{\text { Sansanych is a true idealist. He is not just }}$ the chief editor, but also the heart of the editorial board. He encourages every member of the editorial board and takes care of them, he is always in touch, always understands, always smiles.

Evgeniy and Rosalia. He is cunning, she is beautiful. Their work is the most coordinated when they work together. Due to her beauty, Rosalia has many connections in the city authorities. Evgeniy is able to get to know the things not available for others due to his cunning. They both do not like to write on boring and complex topics, but they both are irreplaceable. Their weapons are charisma and appearance.

Thus, the authors create a clearly false idea of the work of journalists.

The plot can either develop in the editorial office, or the main character can work as a journalist in the modern $\underline{\text { Russian films and television films. So, }}$ the NTV channel has attempted to form an image of an impudent employee of a local newspaper that gathers gossip in the audience. The topic of this profession is less often identified in cinema. In the movie "Urgent Marry", released in wide rental at the end of 2015, the heroine works in a family journal. She gets to know that the Director General should soon leave his post and he needs a 
ISSN | 2179-7137 | http://periodicos.ufpb.br/ojs2/index.php/ged/index

replacement. Since the journal is about family and it should be managed by a family man, the journalist states that she has a wedding in a week. So the romantic plot of the movie starts. Stinging words, planers, poor work with the recorder and complete inability to ask questions these are the main characteristics of journalists represented in the film.

As a result of the study, the authors of this article have concluded that there is no image of an ideal journalist in Russian works of mass culture; the authors tend to exaggerate the image of not the best qualities of a universal journalist.

As a result, there is a stereotype that does not always give birth to a positive idea of journalism. We believe that when creating the works of mass culture, one need to gradually get rid of social labels and create such works that give a true idea of the professional sphere that is reflected in the works of Russian writers and filmmakers.

The spreading of false ideas about the journalist profession is fraught with involving young people in the professional activities that are guided by the journalist images perceived in the works of mass culture that replicates the simulacra and reduces the role of mass media in forming the future society.

If in the late 1960s the entrant focused on the journalist image created in the movie "The Journalist" by Sergey Gerasimov, where the main character found personal happiness in the process of fulfilling a professional duty, then in the late 1980s the journalist image created in the movie "Your Special Correspondent" by Nikolay Gibu, was focused on the opposition of a person defending the truth and the crowd, ready to sacrifice this truth for the sake of personal benefits.

We feel an urgent need for additional scientific literature on this topic, since its study is minimal at the present time. The study of the public opinion formation on the journalism role in the society will adjust the list of competencies developed in the course of professional training.

\section{Discussion}

The results of our study supplement the conclusions of M.C. Ehrlich (2015) [12], J. Salzman, L. Mitchell (2013) [13] about how a modern journalist is represented in the 
ISSN | 2179-7137 | http://periodicos.ufpb.br/ojs2/index.php/ged/index

works of mass culture with the current Russian practice. There are the differences, and one of them is that the Russian authors of media texts often form negative public opinion to journalists, presenting them as greedy, unprincipled persons violating professional ethics. However, the above mentioned researchers have identified attempts of an objective view of the journalist professional activity, who turns out to be a positive character in most works in the works of mass culture published or broadcast outside Russia.

\section{Acknowledgements}

The work is performed according to the

Russian Government Program of Competitive Growth of Kazan Federal University.

\section{References}

Randall, D. (2000). Universal Journalist / Translated from English language by A. Poryaz. St. Petersburg: National Press Institute, 160 p. (in Russ.)

Dmitrieva, D.G. (2015). Age of Superheroes: Roots, History, Ideology of the American Comics. M.: Izoteka, 320 p. (in Russ.)
Khalilov, V.M. (2007). Transformation of Journalist Image and Press Image in the Cinema of the United States at the Beginning of the XII Century // Russia and America in the XXI Century: Electronic Scientific Journal. Available at:

http://www.rusus.ru/?act=read\&id=46 (in Russ.).

Antipova, K.M. (2013). Formation of Journalist Media Image in Contemporary Cinema // International Journal "Media. Information. Communication". Available at: http://mic.org.ru/6-nomer-2013/212formirovanie-mediaobraza-zhurnalistav-sovremennom-kinematografe (in Russ.).

Lazutina, G.V. (2006). Professional Journalist Ethics. M.: Aspect Press, 240 p. (in Russ.)

Markova, G.I. (1996). Mass Culture: Content and Social Functions. M., P.37. (in Russ.)

King, E., Reddick, R. (2000). The Online Journalist $3^{\text {rd }}$. Wadsworth Publishing (C) $2000,288 \mathrm{p}$. 
Denson, S., Meyer, C., Stein, D. (2013). Transnational Perspectives on Graphic Narratives. Bloomsbury Academic, 296 p.

Newman, N. (2009). The rise of social media and its impact on mainstream journalism: A study of how newspapers and broadcasters in the UK and US are responding to a wave of participatory social media, and a historic shift in control towards individual consumers. Available at: http://www.sssup.it/UploadDocs/6635 8 S_The rise_of_Social_Media_and_it s_Impact_on_mainstream_journalism Newman 07.pdf

Deuze, M. (2004). What is multimedia journalism? Journalism Studies. Vol. 5. No. 2, pp. 139-152.

Ehrlich, M.C. (2004). Journalism in the movies. University of Illinois Press, 195 p.

Ehrlich, M.C. (2015). The Heroes and Scoundrels Journalist in Popular Culture Project. University of Illinois Press. Available at: http://www.ijpc.org/page/heroes_and_sc oundrels.

Salzman, J., Mitchell, L. (2013). The image of the Washington journalist in movies and television 1932-2013. Available at: http://www.ijpc.org/page/ijpc_washingt on 